\title{
Thermal Heterogeneity in River Floodplains
}

\section{Journal Article}

Author(s):

Tonolla, Diego; Acuña, Vicenç; Uehlinger, Urs; Frank, Thomas; Tockner, Klement

Publication date:

2010

Permanent link:

https://doi.org/10.3929/ethz-b-000028160

Rights / license:

In Copyright - Non-Commercial Use Permitted

Originally published in:

Ecosystems 13(5), https://doi.org/10.1007/s10021-010-9350-5 


\title{
Thermal Heterogeneity in River Floodplains
}

\author{
Diego Tonolla, ${ }^{1,2,3 *}$ Vicenç Acuña, ${ }^{2,4}$ Urs Uehlinger, ${ }^{2}$ Thomas Frank, ${ }^{5}$ \\ and Klement Tockner ${ }^{1,2,3}$
}

\begin{abstract}
${ }^{1}$ Leibniz-Institute of Freshwater Ecology and Inland Fisheries, IGB, Müggelseedamm 310, 12587 Berlin, Germany; ${ }^{2}$ Swiss Federal Institute of Aquatic Science and Technology, EAWAG, Überlandstrasse 133, 8600 Dübendorf, Switzerland; ${ }^{3}$ Institute of Biology, Freie Universität Berlin, Takustrasse 3, 14195 Berlin, Germany; ${ }^{4}$ Catalan Institute for Water Research, ICRA, Carrer Emili Grahit 101, Parc Científic i Tecnològic de la Universitat de Girona, 17003 Girona, Spain; ${ }^{5}$ Swiss Federal Laboratories for Material Testing and Research, EMPA, Überlandstrasse 129, 8600 Dübendorf, Switzerland
\end{abstract}

\begin{abstract}
River floodplains are composed of a shifting mosaic of aquatic and terrestrial habitats. Each habitat type exhibits distinct environmental and ecological properties. Temperature is a key property driving ecological processes and controlling the composition and distribution of biota. However, given the size and complexity of floodplains, ground surveys based on point measurements are spatially limited. In this study, we applied thermal infrared (IR) imagery to quantify surface temperature patterns at 12-15 min intervals over $24 \mathrm{~h}$ cycles in two nearnatural Alpine river floodplains (Roseg, Tagliamento). Furthermore, vertical temperature distribution was measured at 3-5 min intervals in unsaturated gravel sediment deposits (at $1 \mathrm{~cm}$ distances; 0-29 cm depth). Each habitat type exhibited a distinct thermal signature creating a complex thermal mosaic. The diel temperature pulse and maximum daily temperature were the main thermal components that differentiated habitat types.
\end{abstract}

Received 26 January 2010; accepted 22 May 2010; published online 25 June 2010

Electronic supplementary material: The online version of this article (doi:10.1007/s10021-010-9350-5) contains supplementary material, which is available to authorized users.

Author Contributions: DT analyzed the data and compiled the paper. VA contributed to the data analyses and the text. UU managed the field work and collected the data. TF contributed to the IR data analyses and advised on IR methodology. KT initiated and co-designed the study and contributed to the final version of the text.

*Corresponding author; e-mail: tonolla@igb-berlin.de
In both floodplains, exposed gravel sediments exhibited the highest diel pulse (up to $23^{\circ} \mathrm{C}$ ), whereas in aquatic habitats the pulse was as low as $11^{\circ} \mathrm{C}$ (main channel in the Roseg floodplain). In the unsaturated gravel sediment deposits, the maximum diel kinetic temperature pulse ranged from $40.4^{\circ} \mathrm{C}$ (sediment surface) to $2.7^{\circ} \mathrm{C}(29 \mathrm{~cm}$ sediment depth). Vertically, the spatiotemporal variation of temperature was about as high as horizontally across the entire floodplain surface. This study emphasized that remotely sensed thermal IR imagery provides a powerful non-invasive method to quantitatively assess thermal heterogeneity of complex aquatic and terrestrial ecosystems at a resolution required to understand ecosystem processes and the distribution of biota.

Key words: thermal infrared imagery; remote sensing thermography; IR; temperature; floodplain; river landscape; Tagliamento; Roseg.

\section{INTRODUCTION}

Temperature is a master variable driving physical, chemical, and biological processes in aquatic and terrestrial ecosystems and controlling the composition, distribution, and behavior of organisms (Thyssen and others 1987; Elliott and Hurley 2001; Acuña and others 2008; Hannah and others 2008; Indermaur and others 2009a, b). In addition, temperature is gaining increasing attention because 
climate change has altered and will continue to alter the temperature regime at local, regional, and global scales (IPCC 2007). Thus, temperature remains a subject of world-wide environmental research (Webb and others 2008).

The thermal regime of streams and rivers is mainly influenced by incoming shortwave solar radiation, air temperature, flow regime, riparian conditions, streambed substrata, and upwelling subsurface water (Webb and Zhang 1999; Malard and others 2001; Webb and others 2003). Although the seasonal, annual, and diel temperature cycles of lotic systems are well studied (for a review see Caissie 2006), little is known about the spatiotemporal heterogeneity of temperature in complex landscapes. Previous studies relied mostly on point measurements to quantify spatial thermal heterogeneity (for example, Arscott and others 2001; Uehlinger and others 2003; Acuña and Tockner 2009). Distributed point measurements, using temperature loggers, reveal information at a high temporal resolution at single locations (Selker and others 2006). However, given the size and complexity of floodplain systems, ground surveys provide spatially limited information. Quantifying thermal heterogeneity at the landscape scale is pivotal in identifying the spatiotemporal distribution of critical habitats (for example, thermal refugia, areas of upwelling subsurface water), and to investigate the utilization of these habitats by both aquatic and terrestrial organism as well as by animals that exhibit complex life cycles (for example, aquatic insects, amphibians). Moreover, information on thermal heterogeneity is required to upscale ecosystem processes from point measurements to entire river floodplains.

Remotely sensed thermal infrared (IR) imagery provides an opportunity to simultaneously map surface temperature of aquatic and terrestrial ecosystems at a spatial resolution relevant for quantifying ecosystem processes and the distribution of biota. IR thermography has been used to estimate the abundance and density of terrestrial mammals such as deer, sheep, and polar bears (Naugle and others 1996; Amstrup and others 2004; Bernatas and Nelson 2004) as well as of aquatic mammals such as whales and walruses (Perryman and others 1999; Udevitz and others 2008). Thermal IR imagery has also been applied for monitoring temperature of volcanoes (Lagios and others 2007), mapping of microbial mats in hot springs (Dunckel and others 2009), and characterizing land surface temperature in urbanized areas (Chudnovsky and others 2004; Hartz and others 2006; Xian 2008). Furthermore, satellite-, airborne-, and ground-based
IR images have been used to characterize the spatial heterogeneity of surface temperature of the ocean (Emery and Yu 1997; Parkinson 2003), lakes and reservoirs (LeDrew and Franklin 1985; Anderson and others 1995; Hook and others 2003), as well as rivers (Torgersen and others 1999; Cherkauer and others 2005; Kay and others 2005; Handcock and others 2006; Loheide and Gorelick 2006; Cardenas and others 2008). Cardenas and others (2008) used thermal IR images to characterize thermal heterogeneity in a small stream during different flow conditions. Smikrud and others (2008) used thermal IR imagery, together with aerial photographs, for floodplain classification (Unuk River, SE Alaska). However, none of those studies used thermal IR imagery to characterize surface temperature of entire river landscapes at both high spatial and temporal resolution.

Floodplains may serve as excellent model systems to elaborate upon the thermal heterogeneity of complex landscapes (Tockner and others 2000, 2010). They are composed of a shifting mosaic of aquatic and terrestrial habitat patches that differ in succession stage, flow regime characteristics, sediment, nutrients, organic matter, and thermal characteristics, all of which are critical factors influencing biological communities and ecosystem processes (Naiman and others 2005; Stanford and others 2005). Furthermore, the unsaturated sediments of gravel-bed rivers form the most extensive albeit neglected floodplain habitat.

The primary goals of this study are (i) to quantify the spatial and temporal thermal heterogeneity of entire river floodplains, (ii) to thermally characterize aquatic and terrestrial floodplain habitat types, and (iii) to quantify vertical temperature patterns within unsaturated gravel sediment deposits. To address these objectives, thermal IR images were collected to characterize surface spatial temperature distribution, and temperature loggers were exposed to quantify vertical temperature distribution in unsaturated gravel sediment deposits. All data were collected in two near-natural Alpine river floodplains over approximately $24 \mathrm{~h}$ cycles.

\section{Materials AND Methods}

\section{Experimental Design}

Thermal IR images were taken at 12-15 min intervals over diel cycles in two Alpine floodplains (Roseg and Tagliamento Rivers, Figure 1; Table 1). The IR camera provided surface temperature data (radiant temperature) at high spatial resolution. Concurrently, temperature loggers were deployed 

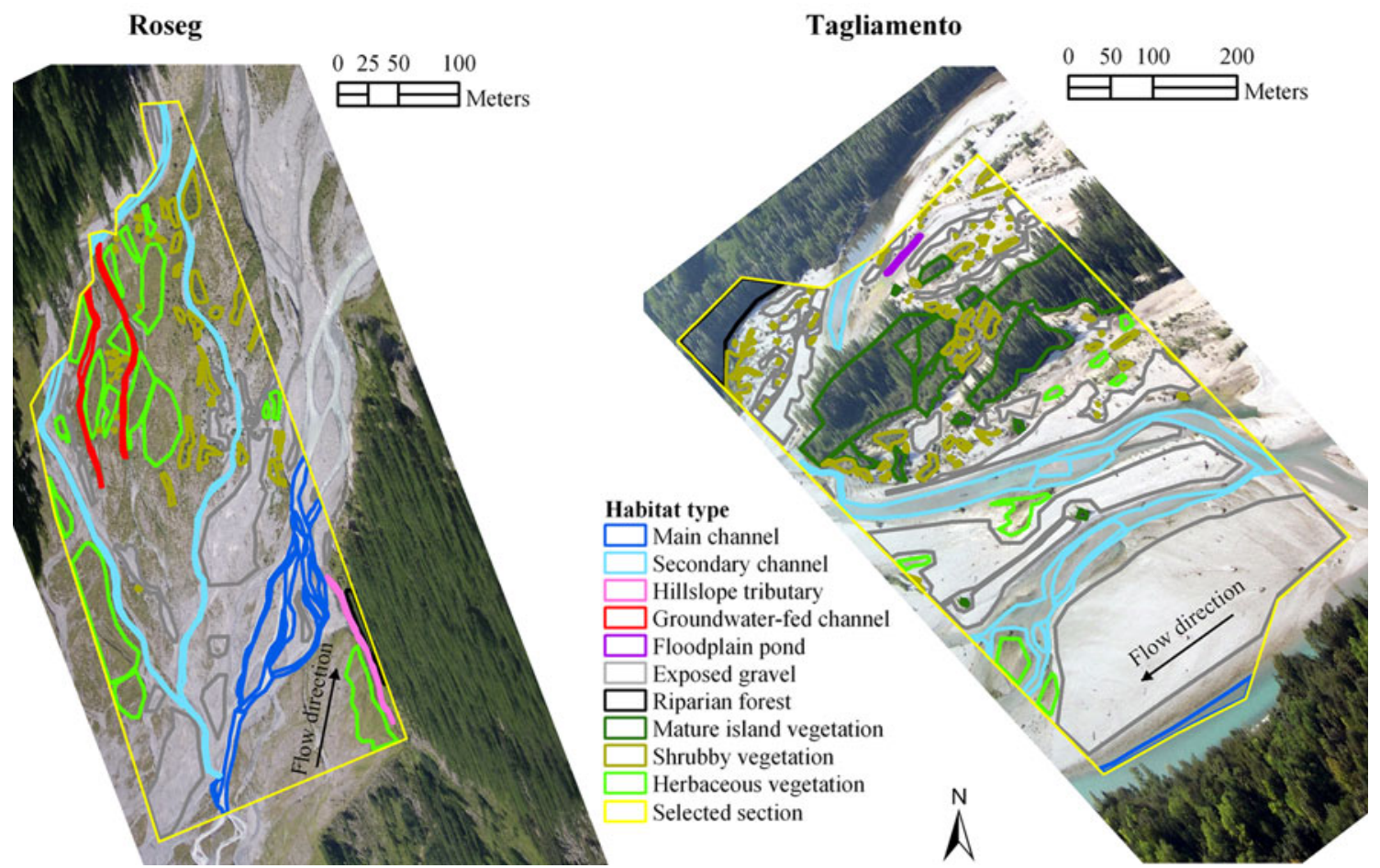

Figure 1. Distribution of aquatic and terrestrial habitat types in the Roseg and Tagliamento Floodplains.

Table 1. Characterization of the Study Sites (Selected Section, Figure 1) and Information on IR Imaging for the Roseg and Tagliamento Floodplains

\begin{tabular}{lll}
\hline Characteristics & Roseg & Tagliamento \\
\hline Study site area (ha) & 9.55 & 27.72 \\
Study site width (m) & $165-340$ & $700-770$ \\
Camera altitude (m asl) & 2240 & 480 \\
Camera distance (m) & $545-1130$ & $530-1300$ \\
Zenith angle $\varphi\left(^{\circ}\right)$ & $65.9-79.3$ & $82.2-84.7$ \\
Final pixel size (m) & $1.66 \times 1.66$ & $2.29 \times 2.29$ \\
Final number of pixels & 34502 & 52531 \\
Sampling start time & 22 Aug. 04 14:12 h & 31 Aug. $0518: 00 \mathrm{~h}$ \\
Sampling end time & 23 Aug. 04 14:12 h & 01 Sep. 05 18:00 h \\
Sampling time interval (min) & 12 & 15 \\
Total number of IR images & 121 & 97
\end{tabular}

in various aquatic and terrestrial habitat types to estimate the difference between radiant (from IR images) and kinetic temperature (from temperature loggers). Furthermore, vertical kinetic temperature distribution was measured in the top layer $(0-29 \mathrm{~cm}$ depth $)$ of unsaturated gravel sediment deposits at $1 \mathrm{~cm}$ intervals.

\section{Study Sites}

The proglacial floodplain of the second-order Roseg River $\left(46^{\circ} 25^{\prime} 37.84^{\prime \prime} \mathrm{N}, 9^{\circ} 51^{\prime} 40.94^{\prime \prime} \mathrm{E}\right)$ is located at
$2000 \mathrm{~m}$ asl in the Bernina massif (Eastern Swiss Alps, Figure 1; Table 1). The floodplain is characterized by various channel types that differ in hydrology and morphology (Tockner and others 2002; Uehlinger and others 2003). About $85 \%$ of the floodplain is composed of exposed gravel or sparsely vegetated areas (Wellstein and others 2003). A detailed description of the catchment and the floodplain is provided by Ward and Uehlinger (2003). Thermal characteristics of aquatic habitats have been investigated by Malard and others (2001) and Uehlinger and others (2003). 
The near-natural island-braided gravel-bed river floodplain of the seventh-order Tagliamento River $\left(46^{\circ} 12^{\prime} 3.60^{\prime \prime} \mathrm{N}, 12^{\circ} 58^{\prime} 26.40^{\prime \prime} \mathrm{E}\right)$ is located at $160 \mathrm{~m}$ asl at the southern fringe of the European Alps (Northeastern Italy, Figure 1; Table 1). At base flow (approximately $20 \mathrm{~m}^{3} \mathrm{~s}^{-1}$ ), the floodplain contains exposed gravel habitats ( $42 \%$ of total area), riparian forest $(35 \%)$, channel network $(15 \%)$, vegetated islands $(7 \%)$, as well as numerous pools and large wood accumulations (each $0.5 \%$ ) (Langhans and others 2008). Detailed information on the Tagliamento catchment and the floodplain can be found elsewhere (for example, Tockner and others 2003). Thermal characteristics of aquatic habitats along the entire river corridor have been studied by Arscott and others (2001) and Acuña and Tockner (2009).

Air temperature data for the Roseg floodplain were obtained from a meteorological station located at $1.5 \mathrm{~km}$ horizontal distance from the study site (1997 m asl; Figure 2). Solar radiation data were obtained from the Swiss Federal Office of Meteorology (Corvatsch station, $3315 \mathrm{~m}$ asl, at $3.3 \mathrm{~km}$ horizontal distance from the study site; Figure 2). At the Tagliamento floodplain, a portable meteorological station continuously recorded air temperatures $1.5 \mathrm{~m}$ above the ground (Figure 2). The Osservatorio Meteorologico Regionale dell' ARPA FVG (OSMER) provided solar radiation data

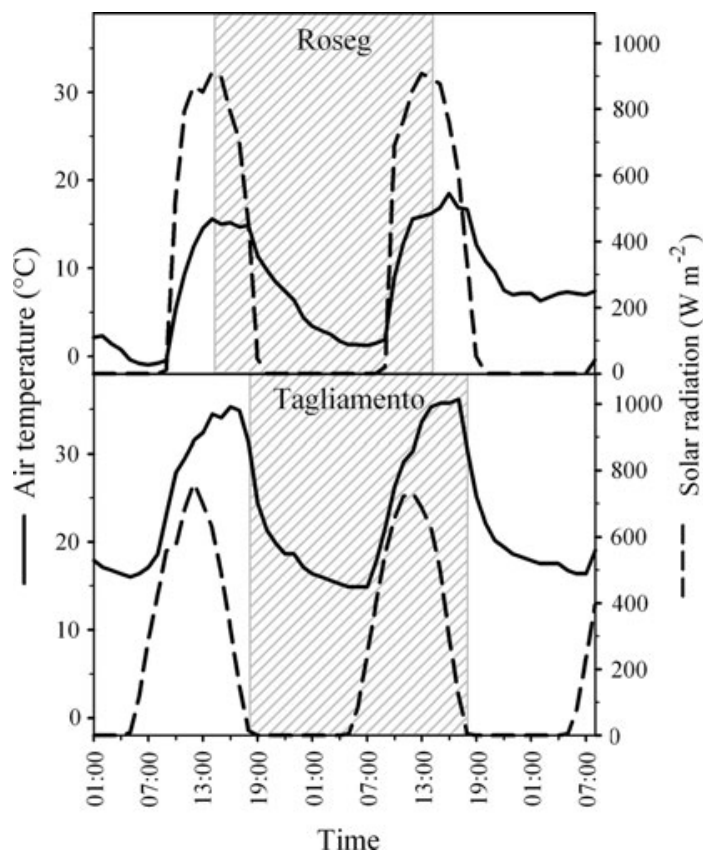

Figure 2. Air temperature and solar radiation in the Roseg (22-24.08.04) and Tagliamento (31.08-02.09.05) floodplains. Shaded area indicates the sampling time of IR-images. from the station Campo Lessi (184 m asl, $13 \mathrm{~km}$ horizontal distance from the study site; Figure 2).

\section{Thermal Characterization of the Floodplains by IR Images}

\section{IR Image Collection}

Oblique IR images were taken with an IR camera (TH 3102 MR, NEC-San-ei Co., Japan) mounted on a tripod installed at the rim of the steep mountains fringing on the two floodplains, thereby allowing the entire valley bottom to be thermally mapped (Figure 1; Table 1). It was possible to take IR images of a floodplain segment at an exceptionally high spatial and temporal resolution that normally could not be achieved using an airborne camera. However, the large zenith angles may have affected the accuracy of the radiant temperature measurements and therefore have to be taken into consideration (Appendices A and B in Supplemental Materials).

The camera was equipped with a Stirling-cooled HgCdTe detector unit operating in the $8-13 \mu \mathrm{m}$ spectral range with a standard thermal recording range $\left(-50-200^{\circ} \mathrm{C}\right)$. The temperature sensitivity (smallest temperature change or difference that can be detected) of the camera was 0.08 at $30^{\circ} \mathrm{C}$ (temperature of the camera itself during the test), the measurement accuracy (level of accuracy of the temperature measurements being recorded by the camera) was $\pm 0.5^{\circ} \mathrm{C}$ (surface temperature range: $0-100^{\circ} \mathrm{C}$; manufacturer's accuracy specifications). The camera used a mirror lens system for scanning a view field of $30^{\circ}$ (horizontal) $\times 28.5^{\circ}$ (vertical) with a horizontal resolution of $1.5 \mathrm{mrad}$ and an image size of 255 pixels $\times 207$ scanning lines.

\section{IR Image Processing}

Thermal data were extracted using the IR image processing software PicWin-IRIS 7.1 (ebs-thermography, Munich, Germany), converted to a georeferenced raster with a specific radiant temperature for each pixel, and post-processed in ArcGIS 9.2 (ESRI, Redlands, California, USA). For further analyses, a subsection of the floodplain was selected based on two criteria: (i) to include all typical aquatic and terrestrial habitat types, and (ii) to minimize shading effects by surrounding landscape elements (Figure 1). Then a network of equally spaced points (one point every $5 \mathrm{~m}$ ) was generated over the thermal raster to extract radiant temperature data for further analysis. This resulted in a reduced data set of approximately 3800 points (Roseg) and approximately 11100 points (Tagliamento), respectively. 
The total size differed for the two river floodplains (Figure 1; Table 1).

The key interest of this study was not to derive the most accurate temperature values at a specific point but to quantify the spatiotemporal variation at the floodplain scale. Nevertheless, because thermal remote sensing is not without shortcomings (for example, Torgersen and others 2001; Handcock and others 2006), we estimated the potential errors of the collected IR imagery (Appendices $\mathrm{A}-\mathrm{C}$ in Supplemental Materials). In this study, the effect of atmospheric absorption was considered negligible because measurement distances were short, and humidity was low during the study period (see Anderson and Wilson 1984; Anderson and others 1995). Moreover, there is relatively little atmospheric absorption in the 8-14 $\mu \mathrm{m}$ spectral band (Anderson and Wilson 1984). IR images were processed assuming a thermal IR emissivity of 1 , which is close to the values of the targeted materials in the studied floodplains (Appendix A in Supplemental Materials). In addition, radiant temperature may be influenced by reflected radiation from the sky and from the surrounding environment as well as from surface roughness (Goldstein 1978; Torgersen and others 2001; Handcock and others 2006). Hence, the potential error due to reflected radiation was considered in the present analyses and the effect of surface roughness was experimentally tested (Appendices B and C in Supplemental Materials).

\section{IR Image Analysis}

Based on the radiant temperature data, six thermal variables were calculated for each point of the regular network: (i) average daily temperature, (ii) minimum daily temperature, (iii) maximum daily temperature, (iv) diel temperature pulse, (v) maximum rate of thermal heating, and (vi) maximum rate of thermal cooling (for calculations see Arscott and others 2001).

A filter of the regular network was necessary to compare thermal characteristics of aquatic and terrestrial habitat types. Thus, polygons encompassing all typical aquatic and terrestrial habitat types were generated and sub-pixel mixing (that is, mixing of pixels from different habitats, for example mixing main channel pixels with exposed gravel pixels) was minimized (Figure 1). Sub-pixel mixing has been shown to affect radiant temperatures (Kay and others 2005; Handcock and others 2006). This resulted in 1170 points from the regular network falling within the habitat polygons in the Roseg and 6260 points in the Tagliamento floodplains, respectively.
At the floodplain scale, the spatial thermal structure was first assessed applying visualization techniques and then through appropriate spatial statistical analyses (Perry and others 2002). A spatial autocorrelation analysis (Global Moran's I) was used to detect if high and/or low thermal values cluster together. A positive Moran's $I$ index value indicates tendency toward clustering whereas a negative Moran's $I$ index value indicates tendency toward dispersion. The $Z$ score indicates whether the statistic value could be the result of random chance or is statistically significant. Spatial statistic calculations were based on Euclidian distance and performed with the six thermal variables calculated for each data point of the regular network (Spatial Statistics Tools of ArcGIS 9.2, ESRI, Redlands, California, USA).

Principal Component Analyses, PCA (R, version 2.9.2, http://www.r-project.org), based on the six thermal variables, were performed to reduce the number of variables. PCA was performed using a correlation matrix to prevent dominant variables from determining the results. Factor loadings of the first and second principal component were extracted without rotation and used for further correlation analyses. Spearman's rank correlation analyses were used to identify direction and strength of associations among the studied variables (SPSS, version 14.0, SPSS Inc., Chicago, Illinois, USA).

To validate radiant temperature values, surface kinetic temperature was concurrently recorded at 10 min intervals with VEMCO Minilog temperature loggers (TR model, AMIRIX Systems Inc., Halifax, NS, Canada; temperature range $-5-35^{\circ} \mathrm{C}$, accuracy $\pm 0.3^{\circ} \mathrm{C}$, resolution $0.2^{\circ} \mathrm{C}$ ) in selected aquatic and terrestrial habitat types. Loggers were placed in protective stainless steel casings (approximately $2.5 \mathrm{~kg}$ ), which have minimal influence on instantaneous temperatures $\left( \pm 0.1^{\circ} \mathrm{C}\right.$; Malard and others 2001).

\section{Vertical Kinetic Temperature Distribution in Unsaturated Gravel Sediment Deposits}

To quantify the vertical kinetic temperature distribution within the top layer of unsaturated gravel sediment deposits, 30 thermocouples, mounted to a PVC frame and connected to a data logger (Squirrel 1000-Serie, Eltek, Cambridge, UK), were buried. Data recording started immediately after the installation of the thermocouples. The loggers were equally spaced between 0 and $29 \mathrm{~cm}$ depth at $1 \mathrm{~cm}$ intervals. An additional thermocouple was mounted $1 \mathrm{~m}$ above the ground surface and shielded against 
direct solar radiation. Data were recorded at $3 \mathrm{~min}$ (Roseg) and 5 min (Tagliamento) intervals.

\section{RESUltS}

\section{Spatiotemporal Thermal Variability at the Floodplain Scale}

At the floodplain scale, surface radiant temperature exhibited a distinct spatiotemporal heterogeneity. Thermally, habitat types differed strongly during day time, whereas surface temperature was relatively uniform across the entire floodplain during night time (Figures 3,4). Habitat-specific properties such as vegetation cover modified the general effect of air temperature and solar shortwave radiation on surface temperature patterns. For example, in the Tagliamento floodplain two distinct temperature peaks occurred at night time and three peaks during day time (Figure 4). During night time, cool aquatic habitats were separated from all terrestrial habitats. During day time, terrestrial habitats could be further thermally differentiated into densely vegetated (riparian forest and mature islands) and pioneer habitat types (that is, exposed gravel, herbaceous and shrubby vegetation) (Figure 3). At the floodplain scale, average daily temperature per pixel ranged between 3.4 and $10.5^{\circ} \mathrm{C}$ (Roseg floodplain) and 16.6 and $24.7^{\circ} \mathrm{C}$ (Tagliamento) (Figure 5). However, diel temperature pulse per

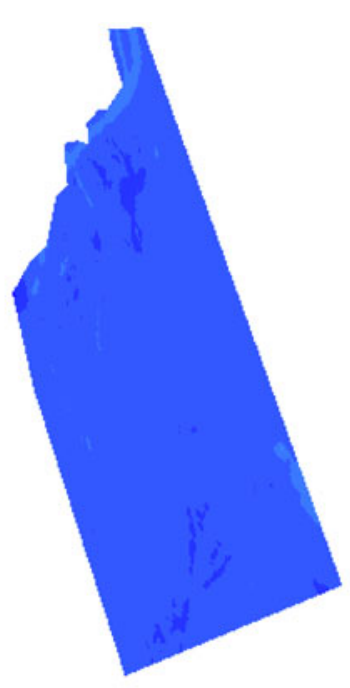

01:00h

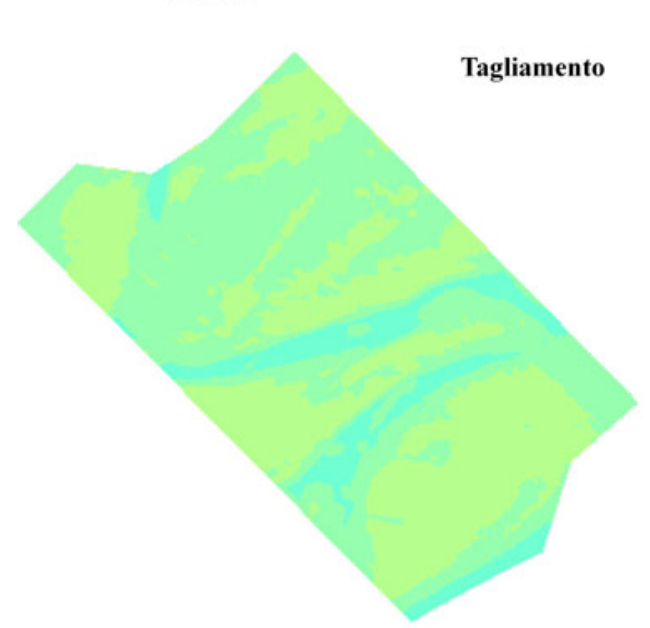

Temperature $\left({ }^{\circ} \mathrm{C}\right)$
Figure 3. Spatial distribution (values per pixel) of surface radiant temperature at 01:00 hours and at 13:00 hours in the Roseg and Tagliamento floodplains.

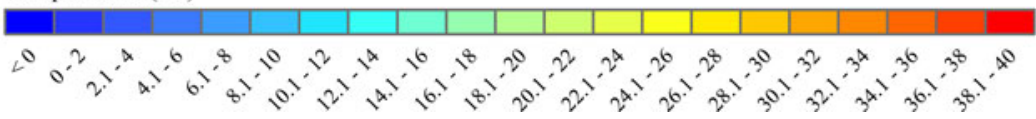




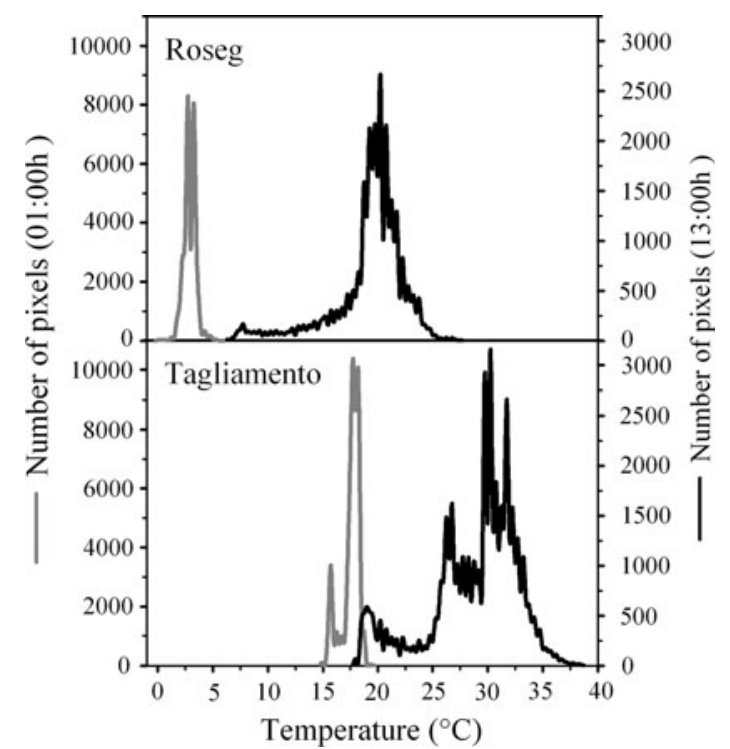

Figure 4. Frequency distribution of pixels in the Roseg and Tagliamento floodplains. Please note different $y$-scales.

pixel ranged in the Roseg from 5.5 to $28.1^{\circ} \mathrm{C}$ and in the Tagliamento from 4.9 to $24.4^{\circ} \mathrm{C}$ (Figure 5).

The global spatial statistic Global Moran's I confirmed that the thermal properties of the individual pixels that emerged over the $24 \mathrm{~h}$ cycles were not the results of random process, but exhibited a distinct degree of clustering that allowed a clear differentiation of thermal patches within the floodplains (Table 2). Moreover, the degree of clustering was higher in the Tagliamento than in the Roseg floodplain (higher $Z$ scores; Table 2).

Aquatic habitats exhibited lower average and pulse values than terrestrial habitats (Table 3). Among all the habitat types, exposed gravels exhibited the highest daily average and diel pulse temperatures. In contrast, vegetation cover attenuated the diel thermal regime (Table 3). Based on six selected thermal variables, the first two components of the PCA explained 91\% (75 and $16 \%$, respectively) of the thermal variance in the Roseg floodplain and $89 \%$ (66 and 23\%, respectively) in the Tagliamento floodplain (Figure 6). The factor scores of the first PCA component were strongly correlated with diel temperature pulse and maximum daily temperature (Table 4). Factor scores of the second PCA component were mainly correlated with minimum daily temperature. The aquatic and terrestrial habitat types could be better differentiated in the Tagliamento than in the Roseg floodplain (Table 4; Figure 6).
Vertical Kinetic Temperature Distribution in Unsaturated Gravel Sediment Deposits

Within the unsaturated gravel sediment deposits kinetic temperature increased with sediment depth during night time, whereas during day time-after a period of rapid temperature alteration in the early morning-it sharply decreased with sediment depth (Figure 7). The diel kinetic temperature pulse ranged from $40.4^{\circ} \mathrm{C}$ (sediment surface) to $2.7^{\circ} \mathrm{C}(29 \mathrm{~cm}$ sediment depth) in the Roseg floodplain and from $28^{\circ} \mathrm{C}$ (sediment surface) to $2.6^{\circ} \mathrm{C}$ $(29 \mathrm{~cm})$ in the Tagliamento floodplain. Over the top $29 \mathrm{~cm}$ sediment layer, daily average kinetic temperature decreased by $5.2^{\circ} \mathrm{C}$ (Roseg) and $2{ }^{\circ} \mathrm{C}$ (Tagliamento). Furthermore, maximum kinetic temperature decreased vertically by $30.4^{\circ} \mathrm{C}$ (Roseg) and $19.9^{\circ} \mathrm{C}$ (Tagliamento). The transfer time of a thermal pulse from the air $(100 \mathrm{~cm}$ above ground level) into the sediment ranged from 100 to $300 \mathrm{~min}$ (both floodplains). In the Tagliamento gravel sediment deposits, there was a delay of 90 min between the maximum air temperature and the maximum kinetic temperature at the sediment surface, $130 \mathrm{~min}$ at $5 \mathrm{~cm}$ depth, $160 \mathrm{~min}$ at $10 \mathrm{~cm}$ depth, and $240 \mathrm{~min}$ at $15 \mathrm{~cm}$ depth (Figure 7). In the Roseg gravel sediment deposits, there was a delay of 60 min between the maximum air temperature and the maximum kinetic temperature at the surface, $150 \mathrm{~min}$ at $5 \mathrm{~cm}$ depth, and $260 \mathrm{~min}$ at 10 and $15 \mathrm{~cm}$ depth (Figure 7).

\section{Discussion}

Remotely sensed IR imagery provides the capacity to map thermal heterogeneity of entire landscapes at a high spatial resolution, a capability not possible using ground-based methods (for example, Torgersen and others 1999, 2001; Loheide and Gorelick 2006). In this study, IR imagery allowed for quantification of surface temperature dynamics in two near-natural Alpine river floodplains characterized by a complex mosaic of habitat patches. The diel dynamics of surface temperature varied considerably across the entire river-floodplain system. For example, the thermal regime of terrestrial habitat patches changed with vegetation cover, corresponding to the succession gradient characteristic for braided river floodplains (Ward and others 2002; Naiman and others 2005). Among the calculated thermal variables, diel temperature pulse and maximum daily temperature separated best the individual habitat types in both river floodplains. Moreover, within the top $29 \mathrm{~cm}$ sediment layer of 


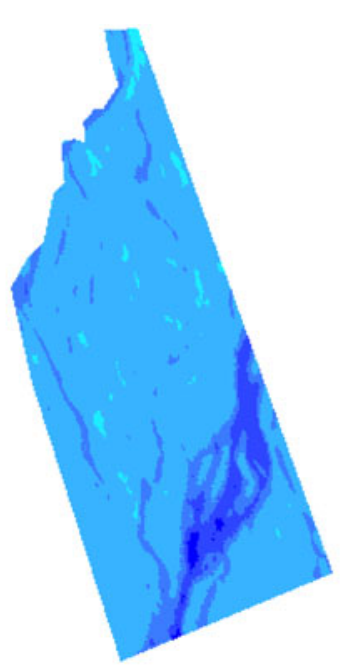

Average

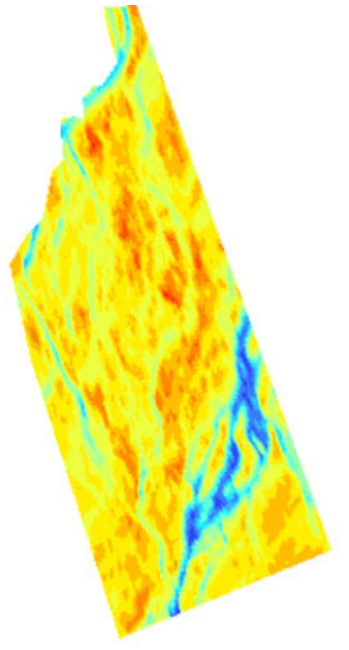

Figure 5. Spatial heterogeneity of average daily temperature and diel temperature pulse in the Roseg and Tagliamento floodplains (values per pixel).

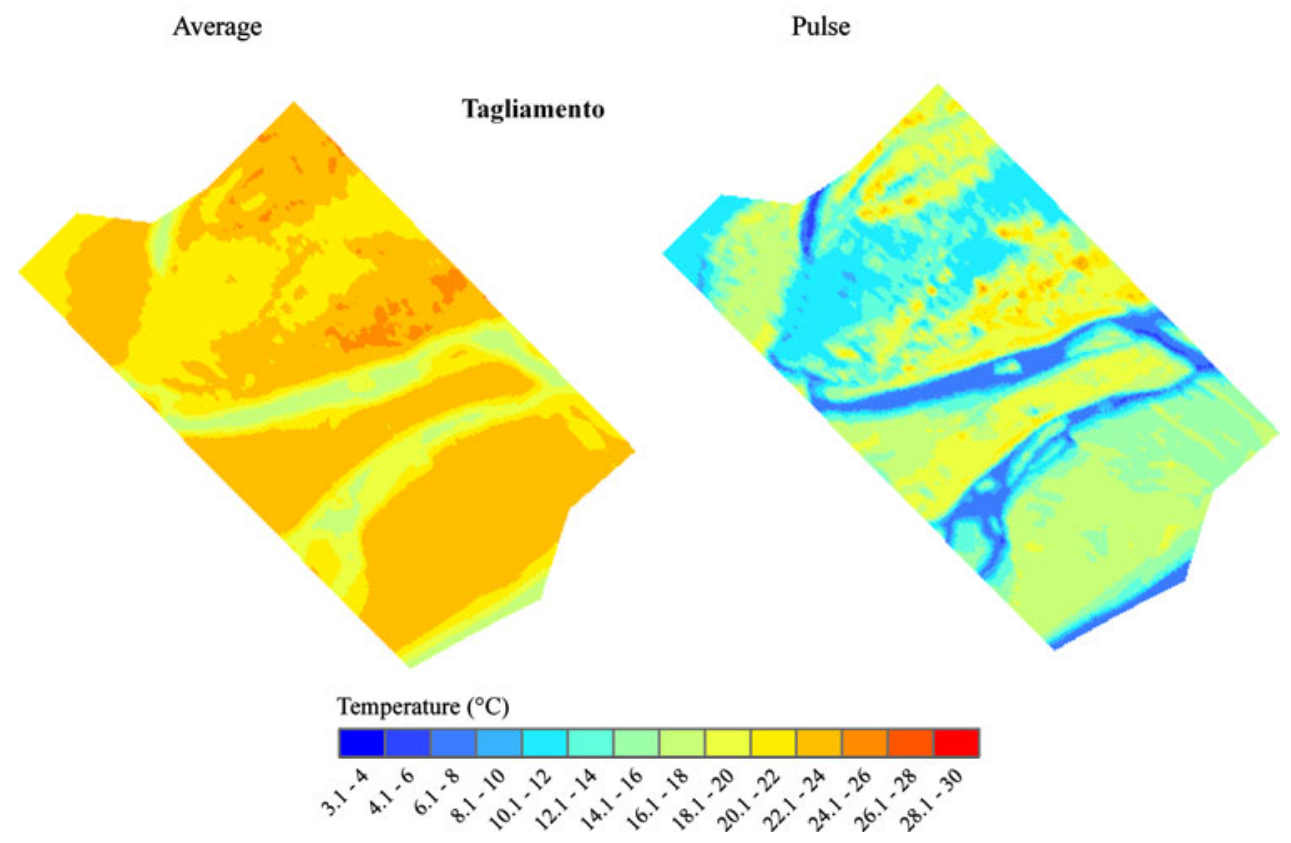

Table 2. Spatial Thermal Autocorrelation (Global Moran's I) for Each Thermal Variable in the Roseg and Tagliamento Floodplains

\begin{tabular}{|c|c|c|c|c|}
\hline & \multicolumn{2}{|l|}{ Roseg } & \multicolumn{2}{|c|}{ Tagliamento } \\
\hline & $I$ index & $Z$ score & $I$ index & $Z$ score \\
\hline Average & 0.48 & $183.5^{*}$ & 0.48 & $362.7^{*}$ \\
\hline Minimum & 0.29 & $110.3^{*}$ & 0.50 & $382.7^{*}$ \\
\hline Maximum & 0.40 & $153.1^{*}$ & 0.44 & $337.2^{*}$ \\
\hline Pulse & 0.39 & $150.5^{*}$ & 0.44 & $332.1^{*}$ \\
\hline Heating & 0.46 & $176.9^{*}$ & 0.30 & $228.3^{*}$ \\
\hline Cooling & 0.25 & $95.6^{*}$ & 0.32 & $243.5^{*}$ \\
\hline
\end{tabular}


Table 3. Thermal Characterization (Average Daily Temperature and Diel Temperature Pulse; Average \pm Standard Deviation; ${ }^{\circ} \mathrm{C}$ ) of Aquatic and Terrestrial Habitat Types in the Roseg and Tagliamento Floodplains

\begin{tabular}{|c|c|c|c|c|}
\hline & \multicolumn{2}{|l|}{ Roseg } & \multicolumn{2}{|c|}{ Tagliamento } \\
\hline & Average & Pulse & Average & Pulse \\
\hline Main channel & $5.2 \pm 1.1$ & $11.2 \pm 4.0$ & $17.4 \pm 0.2$ & $6.9 \pm 0.6$ \\
\hline Secondary channel & $7.6 \pm 0.6$ & $15.9 \pm 3.1$ & $18.1 \pm 0.8$ & $7.7 \pm 1.4$ \\
\hline Hillslope tributary & $7.5 \pm 0.7$ & $15.2 \pm 2.7$ & n.a. & n.a. \\
\hline Groundwater-fed channel & $8.1 \pm 0.5$ & $17.5 \pm 2.5$ & n.a. & n.a. \\
\hline Floodplain pond & n.a. & n.a. & $21.5 \pm 0.5$ & $13.8 \pm 1.3$ \\
\hline Exposed gravel & $8.9 \pm 0.5$ & $22.7 \pm 1.6$ & $23.0 \pm 0.6$ & $17.4 \pm 1.4$ \\
\hline Riparian forest & $8.3 \pm 0.2$ & $14.9 \pm 1.1$ & $21.2 \pm 0.3$ & $11.0 \pm 0.9$ \\
\hline Mature islands & n.a. & n.a. & $21.5 \pm 0.3$ & $11.9 \pm 1.0$ \\
\hline Shrubby vegetation & $8.4 \pm 0.3$ & $19.7 \pm 1.0$ & $22.3 \pm 0.6$ & $14.4 \pm 1.9$ \\
\hline Herbaceous vegetation & $8.7 \pm 0.4$ & $21.1 \pm 1.3$ & $21.9 \pm 0.7$ & $14.7 \pm 1.4$ \\
\hline
\end{tabular}

n.a. not applicable.

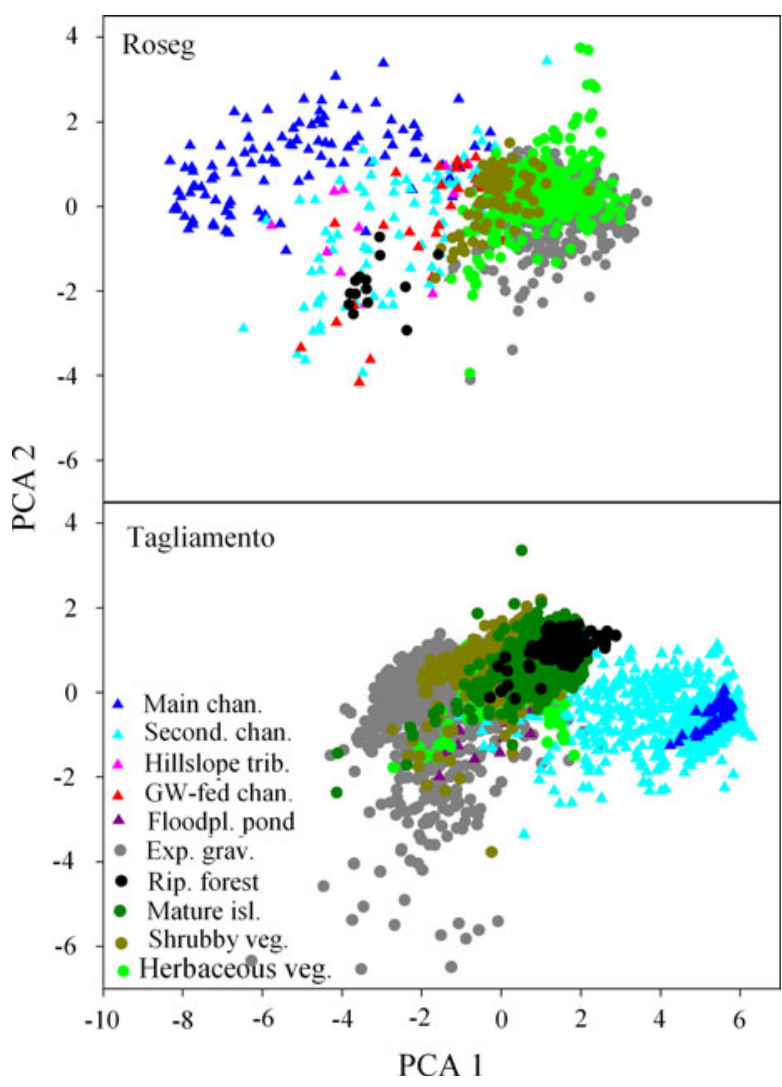

Figure 6. Principal component analysis (PCA) of the Roseg and Tagliamento floodplains based on six thermal variables (see text). Closed triangles show aquatic habitats and closed circles show terrestrial habitats. Only points from the regular network falling within the habitat polygons shown in Figure 1 are represented. For correlations among thermal variables and the factor scores of the components of the PCA see Table 4. the unsaturated zone of gravel sediment deposits, spatiotemporal thermal heterogeneity was almost as high as the thermal heterogeneity across the entire floodplain surface. Results of this study clearly emphasize that traditional ground-based techniques most likely underestimate the spatiotemporal thermal heterogeneity across the riverfloodplain mosaic as well as within the individual habitat. This may have major consequences in calculating and interpreting the effects of temperature on biodiversity patterns and ecosystem processes.

\section{Spatiotemporal Thermal Variability at the Floodplain Scale}

For a comprehensive thermal characterization of river floodplains both aquatic and terrestrial habitats must simultaneously be investigated. Exposed gravel sediments exhibited large diel temperature fluctuations, with maximum surface temperatures of up to $45^{\circ} \mathrm{C}$ during a hot summer day; whereas the main channel and upwelling ground waters provided permanent cool habitat patches (see also Torgersen and others 1999; Baxter and Hauer 2000). As expected, vegetation cover added to the thermal heterogeneity at the floodplain scale as patches of various vegetation cover exhibited distinct thermal properties. For example, woody vegetation cover leads to reduced penetration of solar shortwave radiation at the ground (increased absorption and reflection by the canopy), stores heat under the vegetation canopy, and reduces wind currents. In contrast, open surfaces (that is, exposed gravel and herbaceous vegetation cover) 
Table 4. Spearman's Rank Correlations $(r)$ Between Thermal Variables (see text) and the Factor Scores of the First (PCA 1) and Second (PCA 2) Components of the PCA

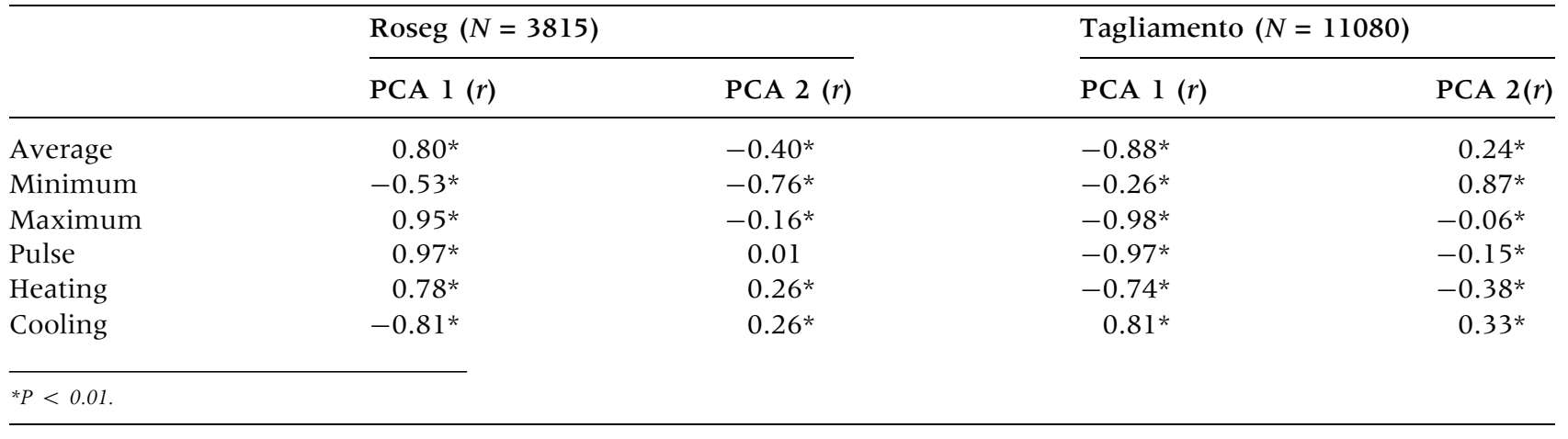

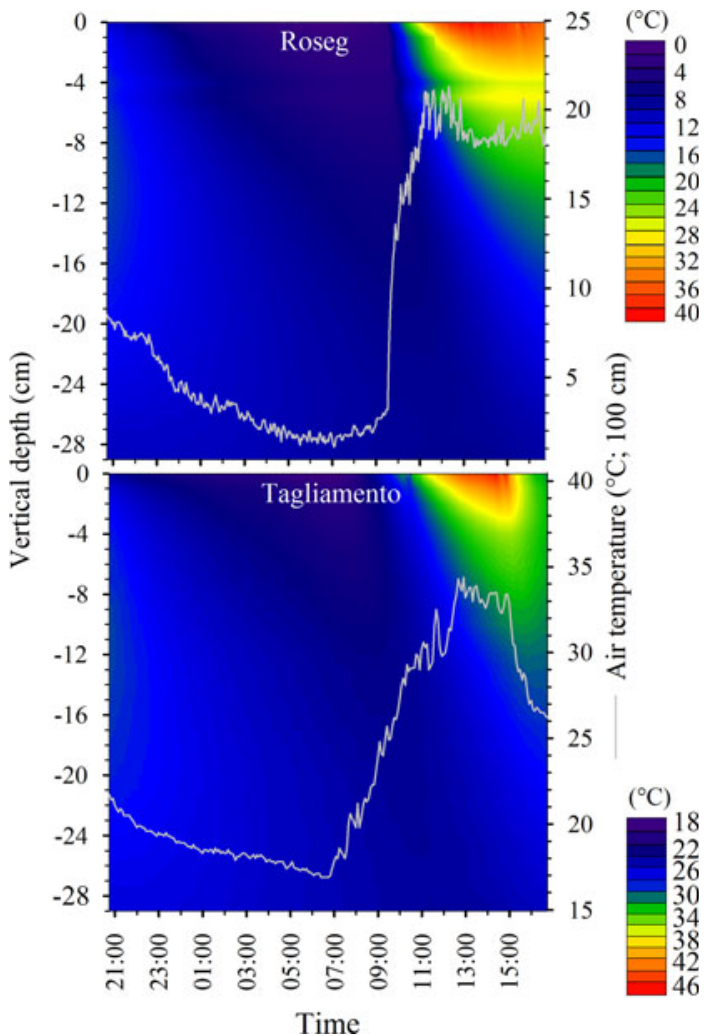

Figure 7. Vertical kinetic temperature distribution $\left(2^{\circ} \mathrm{C}\right.$ steps) in unsaturated gravel sediment deposits of the Roseg (22-23.08.04) and Tagliamento (31.08-01.09.05) floodplains. Surface kinetic temperature $(0 \mathrm{~cm})$ and air temperature $(100 \mathrm{~cm}$ above ground level) are also shown.

exhibit large diel temperature fluctuations because of distinct heat loss at night and direct exposure to solar shortwave radiation during the day. Carlson and Arthur (2000) reported that bare ground and sparsely vegetated surfaces displayed a large variation in radiant surface temperature. The variation decreased-as confirmed in this study-with increasing vegetation density. Densely vegetated habitat types such as the riparian forest exhibited higher surface temperatures during night time and cooler temperatures during day time, as well as a lower diel temperature pulse (amplitude), compared to other terrestrial habitat types (for example, Figure 3 and Table 3; Chudnovsky and others 2004). Daytime cooling was most probably a consequence of latent heat loss through evapotranspiration resulting in reduced longwave radiation emitted from the ground and the leaves. During the night and early morning hours, heat is trapped and stored by the vegetation coverage resulting in reduced direct radiation to the sky (Dimoudi and Nikolopoulou 2003; Dousset and Gourmelon 2003; Chudnovsky and others 2004). In contrast, the lack of an evaporative cooling effect explains the very high surface temperature variation on exposed gravel deposits.

The aquatic habitat types also contributed to the thermal complexity in both floodplains. The variation of water temperature is mainly controlled by air temperature and incoming shortwave solar radiation (for example, Crisp and Howson 1982; Evans and others 1998). However, because aquatic habitat types in both floodplains were characterized by channels of different hydrology and morphology, their heat budget and therefore water temperature differed over the $24 \mathrm{~h}$ cycles. Channel morphology, substratum material, riparian vegetation, and water source may control heat gains and losses and therefore cause strong temperature gradients over short distances (Ward 1985; Webb and Zhang 1997, 1999; Evans and others 1998; Malard and others 2001). For example, Arrigoni and others (2008) found that, compared to the main channel's diel cycle, hyporheic discharge locations typically had similar daily mean temperatures, but smaller diel ranges, creating diverse daytime and nighttime mosaics of surface water temperatures across main, side, and spring channels, despite only minor 
differences in daily mean temperatures among the channels. Furthermore, in the present study, the complex high spatiotemporal variability was also likely related to the influence of subsurface flows to different gravel areas of the floodplains. This may explain the greater dispersion of the floodplain gravel dots in the Tagliamento PCA (Figure 6).

The Tagliamento floodplain exhibited higher average daily temperatures than the Roseg floodplain mainly because of prevailing higher air temperature. Differences between the two floodplains in terms of diel temperature pulses were most likely related to differences in the incoming solar shortwave radiation (higher in the Roseg floodplain), in the amount of water (for example, less water in the main channel and secondary channels in the Roseg floodplain), as well as in the vegetation cover (less dense in the Roseg floodplain). Higher values of diel pulses in the terrestrial habitat types of the Roseg floodplain may have been influenced by high heat loss at night, direct solar radiation during the day, and reduced evaporative cooling effect.

\section{Vertical Kinetic Temperature Distribution in Unsaturated Gravel Sediment Deposits}

Braided gravel-bed rivers are covered by thick layers of unsaturated sediments. This unsaturated zone is likely the most extensive terrestrial habitat along gravel-bed rivers; potentially serving as an important hibernation site or as flood-refugia for terrestrial arthropods (Tockner and others 2006). Vertical strong temperature gradients in both terrestrial (this study) and aquatic (Malard and others 2001) habitats were found in the Roseg and Tagliamento floodplains. A maximum vertical temperature gradient of approximately $30^{\circ} \mathrm{C}$ over a vertical distance of $29 \mathrm{~cm}$ during day time in the Roseg floodplain approximately corresponds to the maximum horizontal thermal range over a distance of several hundred meters across the floodplain surface at noon (Figure 3). In fact, in the Tagliamento a maximum vertical thermal difference of up to $20^{\circ} \mathrm{C}$ at a given time during the day corresponds to the observed difference along the entire $170-\mathrm{km}$ long main river channel (Arscott and others 2001).

In this study, vertical temperature patterns were only quantified in unsaturated gravel sediment deposits, but the magnitude of the observed changes over depth stresses the importance of considering the vertical dimension as a third spatial dimension in future studies. The thermal inertia observed in the unsaturated gravel layers may result from the interaction of the vertical heat transfer with the specific heat capacity of the sediments, which again was most likely influenced by the water content. The low temporal variation in temperature in the floodplain sediment deposits at the subsurface level might explain the reduction in the diel temperature pulse in emerging hyporheic flows reported elsewhere, including the same Tagliamento floodplain (Acuña and Tockner 2009).

\section{Ecological Implications}

Lateral and vertical thermal heterogeneity has been recognized as an important aspect in many ecological studies (for example, Brunke and Gonser 1997; Arscott and others 2001; Ebersole and others 2003; Uehlinger and others 2003). The application of non-invasive IR imagery offers a rapid insight into the temperature regime along river corridors and helps to identify both natural and anthropogenic drivers that may influence thermal landscapes. Furthermore, this technique allows for quantification of spatiotemporal thermal heterogeneity within the individual habitat types (see PCA results and tables), to detect critical hot and cold spots as well as hot and cold moments (sensu McClain and others 2003), to identify the key thermal properties (diel pulse and maximum temperature) that characterize these habitat patches, as well as to quantify the rapidly shifting thermal mosaic at the floodplain scale. This information is expected to be crucial for predicting the effect of environmental heterogeneity on ecosystem processes, biodiversity patterns, and animal behavior, therefore for establishing adequate conservation strategies (for example, Fausch and others 2002). How do organisms exploit temporally dynamic and spatially complex habitats? Does thermal heterogeneity increase the resilience of an ecosystem? How do temperature and flow dynamics interact and control ecosystem processes?

IR imagery may allow quantifying the distribution of thermal refugia, as well as the utilization of these refugia by aquatic and terrestrial animals. The provision of thermal refugia during extreme environmental conditions, such as heat waves, is crucial for the long-term survival of many aquatic (for example, Torgersen and others 1999; Baxter and Hauer 2000) and terrestrial (for example, Schwarzkopf and Alford 1996; Seebacher and Alford 2002) organisms. IR imagery may help in understanding the habitat requirements of many aquatic insects, as well as pond-breeding amphibians, which have complex life cycles with terrestrial stages. The life time fitness of these species is 
affected by the environmental conditions during the larval and adult stages, respectively (for example, Bonte and others 2008; Richter and others 2008). Pond-breeding amphibians spend most of their life in terrestrial habitats where they actively regulate their body temperature and loss of body water through their skin using thermal shelter. Therefore, home range placement of amphibians depends on the thermal properties of the individual habitat types (for example, large wood deposits that provide thermal refugia), as well as on the spatial configuration of these habitats, as demonstrated for the Tagliamento floodplain (Indermaur and others 2009a, b). Moreover, sympatric species differ in their thermal preferences within the same habitat type, implying that thermal heterogeneity may facilitate the co-existence of species (Indermaur and others 2009b). Hence, traditional methods for measuring temperature in different habitats (for example, one or few temperature loggers per habitat type) may not provide the required spatial information for explaining the distribution and behavior of river and floodplain animals within such complex landscapes.

Ecosystem processes that are highly sensitive to temperature, such as respiration, might closely follow diel patterns of temperature (Acuña and others 2008). In particular distinct diel temperature pulses are expected to be highly ecologically relevant-more relevant than the average daily temperature. Ecosystem processes that are controlled by microbial communities (for example, sediment respiration or leaf litter decomposition) may quickly respond and adjust to these diel temperature pulses (Dang and others 2009, and references therein). IR imagery can provide rapid and detailed thermal characterization of river landscapes and might help detecting spatiotemporal changes and trends in temperature patterns, therefore increasing our understanding of ecosystem processes. Furthermore, this technique can reveal information on thermal heterogeneity at a spatial and temporal resolution relevant to upscale ecosystem processes from point measurements to entire river floodplains.

The high thermal heterogeneity within the top sediment layer may influence the spatial distribution of epigeic arthropods. Terrestrial invertebrates may actively seek refuge in deeper gravel sediment layers to avoid heat stress in summer as well as surface freezing during winter. Similarly, vertical migration in response to floods has been identified as an important survival strategy of many terrestrial invertebrates of floodplains (Adis and Junk 2002). The steep vertical temperature gradients might be also reflected in a gradient in the metabolic rates at which ecosystem processes operate, as most processes are temperature driven (Gillooly and others 2001; Brown and others 2004). Ignoring vertical temperature gradients might obscure the relationship between measured ecosystem processes (that are usually integrative over depth and expressed per surface area unit; Döring 2007) and measured surface temperature. It is therefore advisable to consider those temperature gradients when studying ecosystem processes in habitats such as the bare gravel sediment deposits in floodplains.

Finally, we expect that we can greatly attenuate the effects of global warming by manipulating specific characteristics of landscape surfaces. However, ignoring small-scale and short-term thermal heterogeneity may lead to erroneous conclusions about the ecological consequences of future air temperature increases.

\section{ACKNOWLEDGMENTS}

The authors are indebted to C. Tanner (QC-Expert, Spin-Off of the Swiss Federal Laboratories for Material Testing and Research, EMPA) for his professional support with the thermal data acquisition. We thank two anonymous reviewers for their constructive comments and suggestions that helped to improve the manuscript. This study was supported by the Swiss Federal Institute of Aquatic Science and Technology (EAWAG), the LeibnizInstitute of Freshwater Ecology and Inland Fisheries (IGB), and a Marie Curie Intra-European Fellowship to VA within the 6th European Community Framework Programme.

\section{REFERENCES}

Acuña V, Tockner K. 2009. Surface-subsurface water exchange rates along alluvial river reaches control the thermal patterns in an Alpine river network. Freshw Biol 54:306-20.

Acuña V, Wolf A, Uehlinger U, Tockner K. 2008. Temperature dependence of stream benthic respiration in an Alpine river network with relevance to global warming. Freshw Biol 53:2076-88.

Adis J, Junk WJ. 2002. Terrestrial invertebrates inhabiting lowland river floodplains of Central Amazonia and Central Europe: a review. Freshw Biol 47:711-31.

Amstrup SC, York G, McDonald TL, Nielson R, Simac K. 2004. Detecting denning polar bears with forward-looking infrared (FLIR) imagery. Bioscience 54:337-44.

Anderson JM, Wilson SB. 1984. The physical basis of current infrared remote-sensing techniques and the interpretation of data from aerial surveys. Int J Remote Sens 5:1-18.

Anderson JM, Duck RW, McManus J. 1995. Thermal radiometry-a rapid means of determining surface-water temperature-variations in lakes and reservoirs. J Hydrol 173:131-44.

Arrigoni AS, Poole GC, Mertes LAK, O'Daniel SJ, Woessner WW, Thomas SA. 2008. Buffered, lagged, or cooled? Disen- 
tangling hyporheic influences on temperature cycles in stream channels. Water Resour Res 44:W09418.

Arscott DB, Tockner K, Ward JV. 2001. Thermal heterogeneity along a braided floodplain river (Tagliamento River, northeastern Italy). Can J Fish Aquat Sci 58:2359-73.

Baxter CV, Hauer FR. 2000. Geomorphology, hyporheic exchanges, and selection of spawning habitat by bull trout (Salvelinus confluentus). Can J Fish Aquat Sci 57:1470-81.

Bernatas S, Nelson L. 2004. Sightability model for California bighorn sheep in canyonlands using forward-looking infrared (FLIR). Wildl Soc Bull 32:638-47.

Bonte D, Travis JMJ, De Clercq N, Zwertvaegher I, Lens L. 2008. Thermal conditions during juvenile development affect adult dispersal in a spider. Proc Natl Acad Sci USA 105:17000-5.

Brown JH, Gillooly JF, Allen AP, Savage VM, West GB. 2004. Toward a metabolic theory of ecology. Ecology 85:1771-89.

Brunke M, Gonser T. 1997. The ecological significance of exchange processes between rivers and groundwater. Freshw Biol 37:1-33.

Caissie D. 2006. The thermal regime of rivers: a review. Freshw Biol 51:1389-406.

Cardenas MB, Harvey JW, Packman AI, Scott DT. 2008. Groundbased thermography of fluvial systems at low and high discharge reveals potential complex thermal heterogeneity driven by flow variation and bioroughness. Hydrol Process 22:980-6.

Carlson TN, Arthur ST. 2000. The impact of land use-land cover changes due to urbanization on surface microclimate and hydrology: a satellite perspective. Global Planet Change 25:49-65.

Cherkauer KA, Burges SJ, Handcock RN, Kay JE, Kampf SK, Gillespie AR. 2005. Assessing satellite-based and aircraft-based thermal infrared remote sensing for monitoring Pacific Northwest river temperature. J Am Water Resour Assoc 41:1149-59.

Chudnovsky A, Ben-Dor E, Saaroni H. 2004. Diurnal thermal behaviour of selected urban objects using remote sensing measurements. Energy Build 36:1063-74.

Crisp DT, Howson G. 1982. Effect of air-temperature upon mean water temperature in streams in the Northern Pennines and English Lake District. Freshw Biol 12:359-67.

Dang CK, Schindler M, Chauvet E, Gessner MO. 2009. Temperature oscillation coupled with fungal community shifts can modulate warming effects on litter decomposition. Ecology 90:122-31.

Dimoudi A, Nikolopoulou M. 2003. Vegetation in the urban environment: microclimatic analysis and benefits. Energy Build 35:69-76.

Döring M. 2007. Environmental heterogeneity and respiration in a dynamic river corridor: Structural properties and functional performance. Dissertation ETH-Zurich no. 17046.

Dousset B, Gourmelon F. 2003. Satellite multi-sensor data analysis of urban surface temperatures and landcover. ISPRS J Photogramm Remote Sens 58:43-54.

Dunckel AE, Cardenas MB, Sawyer AH, Bennett PC. 2009. Highresolution in situ thermal imaging of microbial mats at El Tatio Geyser, Chile, shows coupling between community color and temperature. Geophys Res Lett 36:L23403.

Ebersole JL, Liss WJ, Frissell CA. 2003. Cold water patches in warm streams: physicochemical characteristics and the influence of shading. J Am Water Resour Assoc 39:355-68.
Elliott JM, Hurley MA. 2001. Modelling growth of brown trout, Salmo trutta, in terms of weight and energy units. Freshw Biol 46:679-92.

Emery WJ, Yu Y. 1997. Satellite sea surface temperature patterns. Int J Remote Sens 18:323-34.

Evans EC, McGregor GR, Petts GE. 1998. River energy budgets with special reference to river bed processes. Hydrol Process 12:575-95.

Fausch KD, Torgersen CE, Baxter CV, Li HW. 2002. Landscapes to riverscapes: bridging the gap between research and conservation of stream fishes. Bioscience 52:483-98.

Gillooly JF, Brown JH, West GB, Savage VM, Charnov EL. 2001. Effects of size and temperature on metabolic rate. Science 293:2248-51.

Goldstein RJ. 1978. Application of aerial infrared thermography to the measurement of building heat loss. ASHRAE Trans 84:207-26.

Handcock RN, Gillespie AR, Cherkauer KA, Kay JE, Burges SJ, Kampf SK. 2006. Accuracy and uncertainty of thermalinfrared remote sensing of stream temperatures at multiple spatial scales. Remote Sens Environ 100:427-40.

Hannah DM, Webb BW, Nobilis F. 2008. River and stream temperature: dynamics, processes, models and implicationspreface. Hydrol Process 22:899-901.

Hartz DA, Prashad L, Hedquist BC, Golden J, Brazel AJ. 2006. Linking satellite images and hand-held infrared thermography to observed neighborhood climate conditions. Remote Sens Environ 104:190-200.

Hook SJ, Prata FJ, Alley RE, Abtahi A, Richards RC, Schladow SG, Pálmarsson SO. 2003. Retrieval of lake bulk and skin temperatures using Along-Track Scanning Radiometer (ATSR2) data: a case study using Lake Tahoe, California. J Atmos Ocean Technol 20:534-48.

Indermaur L, Gehring M, Wehrle W, Tockner K, Näf-Dänzer B. 2009a. Behavior-based scale definitions for determining individual space use: requirement of two amphibians. Am Nat 173:60-71.

Indermaur L, Winzeler T, Schmidt BR, Tockner $\mathrm{K}$, Schaub M. 2009b. Differential resource selection within shared habitat types across spatial scales in sympatric toads. Ecology 90:3430-44.

IPCC. 2007. Fourth assessment report on climate change. The Intergovernmental Panel of Climate Change. http://www. ipcc.ch/, 20 April 2010.

Kay JE, Kampf SK, Handcock RN, Cherkauer KA, Gillespie AR, Burges SJ. 2005. Accuracy of lake and stream temperatures estimated from thermal infrared images. J Am Water Resour Assoc 41:1161-75.

Lagios E, Vassilopoulou S, Sakkas V, Dietrich V, Damiata BN, Ganas A. 2007. Testing satellite and ground thermal imaging of low-temperature fumarolic fields: the dormant Nisyros volcano (Greece). ISPRS J Photogramm Remote Sens 62:447-60.

Langhans SD, Tiegs SD, Gessner MO, Tockner K. 2008. Leafdecomposition heterogeneity across a riverine floodplain mosaic. Aquat Sci 70:337-46.

LeDrew EF, Franklin SE. 1985. The use of thermal infrared imagery in surface current analysis of a small lake. Photogramm Eng Remote Sens 51:565-73.

Loheide SP, Gorelick SM. 2006. Quantifying stream-aquifer interactions through the analysis of remotely sensed thermographic profiles and in situ temperature histories. Environ Sci Technol 40:3336-41. 
Malard F, Mangin A, Uehlinger U, Ward JV. 2001. Thermal heterogeneity in the hyporheic zone of a glacial floodplain. Can J Fish Aquat Sci 58:1319-35.

McClain ME, Boyer EW, Dent CL, Gergel SE, Grimm NB, Groffman PM, Hart SC, Harvey JW, Johnston CA, Mayorga E, McDowell WH, Pinay G. 2003. Biogeochemical hot spots and hot moments at the interface of terrestrial and aquatic ecosystems. Ecosystems 6:301-12.

Naiman RJ, Décamps H, McClain ME, Eds. 2005. Riparia: ecology, conservation, and management of streamside communities. Amsterdam: Elsevier Academic Press.

Naugle DE, Jenks JA, Kernohan BJ. 1996. Use of thermal infrared sensing to estimate density of white-tailed deer. Wildl Soc Bull 24:37-43.

Parkinson CL. 2003. Aqua: an earth-observing satellite mission to examine water and others climate variables. IEEE Trans Geosci Remote Sens 41:173-83.

Perry JN, Liebhold AM, Rosenberg MS, Dungan J, Miriti M, Jakomulska A, Citron-Pousty S. 2002. Illustrations and guidelines for selecting statistical methods for quantifying spatial pattern in ecological data. Ecography 25:578-600.

Perryman WL, Donahue MA, Laake JL, Martin TE. 1999. Diel variation in migration rates of eastern pacific gray whales measured with thermal imaging sensors. Mar Mamm Sci 15:426-45.

Richter O, Suhling F, Mueller O, Kern D. 2008. A model for predicting the emergence of dragonflies in a changing climate. Freshw Biol 53:1868-80.

Schwarzkopf L, Alford RA. 1996. Desiccation and shelter-site use in a tropical amphibian: comparing toads with physical models. Funct Ecol 10:193-200.

Seebacher F, Alford RA. 2002. Shelter microhabitats determine body temperature and dehydration rates of a terrestrial amphibian (Bufo marinus). J Herpetol 36:69-75.

Selker JS, Thévenaz L, Huwald H, Mallet A, Luxemburg W, van de Giesen N, Stejskal M, Zeman J, Westhoff M, Parlange MB. 2006. Distributed fiber-optic temperature sensing for hydrologic systems. Water Resour Res 42:W12202.

Smikrud KM, Prakash A, Nicholos JV. 2008. Decision-based fusion for improved fluvial landscape classification using digital aerial photographs and forward looking infrared images. Photogramm Eng Remote Sens 74:903-11.

Stanford JA, Lorang MS, Hauer FR. 2005. The shifting habitat mosaic of river ecosystems. Verh Int Ver Theor Angew Limnol 29:123-36.

Thyssen N, Erlandsen M, Jeppesen E, Ursin C. 1987. Reaeration of oxygen in shallow, macrophyte rich streams: I. Determination of the reaeration rate coefficient. Int Rev Gesamten Hydrobiol 72:405-29.

Tockner K, Malard F, Ward JV. 2000. An extension of the flood pulse concept. Hydrol Process 14:2861-83.
Tockner K, Malard F, Uehlinger U, Ward JV. 2002. Nutrients and organic matter in a glacial river-floodplain system (Val Roseg, Switzerland). Limnol Oceanogr 47:266-77.

Tockner K, Ward JV, Arscott DB, Edwards PJ, Kollmann J, Gurnell AM, Petts GE, Maiolini B. 2003. The Tagliamento River: an ecosystem of European importance. Aquat Sci 65:239-53

Tockner K, Karaus U, Paetzold A, Claret C, Zettel J. 2006. Ecology of braided rivers. In: Sambrook Smith GH, Best JL, Bristow C, Petts GE, Eds. Ecology of braided rivers. Oxford: IAS Special Publication, Blackwell Science. p 339-58.

Tockner K, Lorang MS, Stanford JA. 2010. River flood plains are model ecosystems to test general hydrogeomorphic and ecological concepts. River Res Appl 26:76-86.

Torgersen CE, Price DM, Li HW, McIntosh BA. 1999. Multiscale thermal refugia and stream habitat associations of chinook salmon in northeastern Oregon. Ecol Appl 9:301-19.

Torgersen CE, Faux RN, McIntosh BA, Poage NJ, Norton DJ. 2001. Airborne thermal remote sensing for water temperature assessment in rivers and streams. Remote Sens Environ 76:386-98

Udevitz MS, Burn DM, Webber MA. 2008. Estimation of walrus populations on sea ice with infrared imagery and aerial photography. Mar Mamm Sci 24:57-70.

Uehlinger U, Malard F, Ward JV. 2003. Thermal patterns in the surface waters of a glacial river corridor (Val Roseg, Switzerland). Freshw Biol 48:284-300.

Ward JV. 1985. Thermal-characteristics of running waters. Hydrobiologia 125:31-46.

Ward JV, Malard F, Tockner K. 2002. Landscape ecology: a framework for integrating pattern and process in river corridors. Landscape Ecol 17:34-45.

Ward JV, Uehlinger U, Eds. 2003. Ecology of a glacial flood plain. Dordrecht: Kluwer Academic Publisher.

Webb BW, Zhang Y. 1997. Spatial and seasonal variability in the components of the river heat budget. Hydrol Process 11:79-101.

Webb BW, Zhang Y. 1999. Water temperatures and heat budgets in Dorset chalk water courses. Hydrol Process 13:309-21.

Webb BW, Clack PD, Walling DE. 2003. Water-air temperature relationships in a Devon river system and the role of flow. Hydrol Process 17:3069-84.

Webb BW, Hannah DM, Moore RD, Brown LE, Nobilis F. 2008. Recent advances in stream and river temperature research. Hydrol Process 22:902-18.

Wellstein C, Uehlinger U, Zah R. 2003. Terrestrial floodplain vegetation. In: Ward JV, Uehlinger U, Eds. Ecology of a glacial flood plain. Dordrecht: Kluwer Academic Publisher. p 109-21.

Xian G. 2008. Satellite remotely-sensed land surface parameters and their climatic effects for three metropolitan regions. Adv Space Res 41:1861-9. 